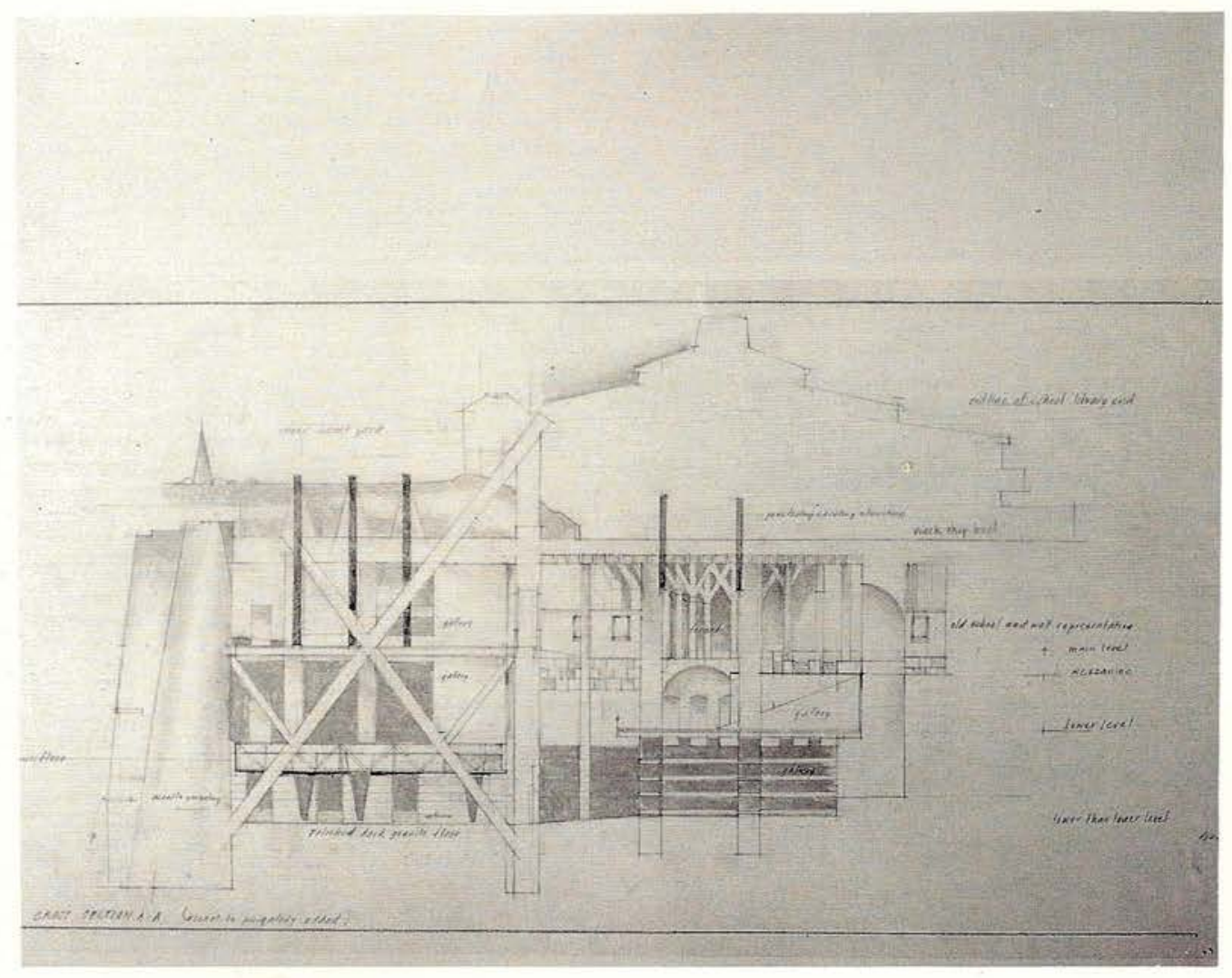




\title{
Architectural Titans: Keats and the Problem of Rebirth
}

\author{
John D Dickson
}

\section{PREFACE}

In this paper cross-reference is made between the New Sacristy of San Lorenzo, Florence; the Quattro Fontane and the Sistine Chapel, Rome; and Keats's Hyperion. A Fragment, The Fall of Hyperion. A Dream, and Sleep and Poetry. These texts are shown to be linked by a common interest in the theme of renewal and the problem of birth. Donato (1979) argues Keats's departure from Wordsworth's belief in what he terms a redemptive history, and takes Hyperion and The Fall of Hyperion to be Keats's statement of the failure of this redemptive history; for Keats far from being inadequate to the task of finishing the poem recognises, Donato asserts, that this narrative of Apollo's birth cannot be completed because of a failure by the 'already dead' Apollo to be born. 1 This failure of the Olympian programme and the redemptive scheme it sustains, as perceived by Keats and discussed by Donato, has fascinating implications for reading the selected Renaissance texts.

Crucial to Pope Leo X's conception of the New Sacristy tomb, is anxiety at the imminent extinction of the Medici Dynasty and a flickering of new hope with the birth of a legitimate heir, Cosimo.2 There is anxiety also concerning the fortunes of the Roman Church with the advent of Luther's Protestantism. ${ }^{3}$ The theme of resurrection, of personal significance to Pope Leo, becomes a crucial image for the Roman Church's conception of self renewal. Self-styled as Sol-Apollo, Pope Leo clears the way for the resurrected Christ to be styled likewise as Apollo. 4 With the death of Pope Leo these themes are notably unfulfilled in the New Sacristy tomb, but reappear in relation to the Sistine Chapel where the resurrected Christ-Apollo is eventually painted by Michelangelo. But can this figure be Apollo? A reading of Keats alerts the viewer to the significance of the titanic condition of the Christ figure and of the enormous composition of which it is part, perhaps otherwise simply understood as Michelangelo's Roman style. 5

It is suggested that this depiction of rebirth can be understood as the titanic appropriation of Apollo's birth, involving the simultaneous presence of the Olympians and the Titans. The coincidence of the golden age of Virgil's peaceful
John Dickson graduated with a PhD in Architectural Theory from the School of Architecture, University of Auckland where he is currently a Senior Lecturer in Architectural History and Theory and tutors Architectural Design. He has a special interest in Ancient and Medieval Architecture of the Middle East.

1. Eugenio Donato 'Divine Agonies: Of

Representation and Narrative in Romantic Poetics' in Glyph 6, Baltimore: John Hopkins University Press, 1979.

2. Janet Cox-Rearick, Dynasty and Destiny in Medici Art. Pontormo, Leo $X$, and the Two Cosimos, Princeton, New Jersey: Princeton University. Press, 1984; p. 43.

3. Frederick Hartt The Drawings of Michelangelo, London: Thames and Hudson, 1971; p. 181.

4. Cox-Rearick, 1987, p. 137.

5. Charles de Tolnay Michelangelo, Sculptor, Painter, Architect, Princeton, New Jersey: Princeton University Press, 1981; p. 51.

opp. Roger Fairey, Museum of Architecture for the University of Auckland (1985) 
6. Cox-Rearick, 1984, p. 133.

7. Donato, 1979 , p. 110 . Donato sees the nursery rhyme 'Humpty Dumpty' as a metaphor for the failure of a redemptive history.

8. Roger Fairey graduated in Architecture from Auckland University 1986.

9. Giusepppe Terragni 'Relazione Sul Danteum, $1938^{\prime}$. Translated by Thomas Schumacher, Oppositions 9, 1977, pp. 89-107. agricultural deity Saturn, with Apollo's reign, as depicted in Pontormo's Vertumnus and Pomano lunette fresco in the Salone of Lorenzo il Magnifico's Villa at Poggio a Caiano, is a Medici conceit anticipating Michelangelo's fresco in the Sistine Chapel.6

The later Quattro Fontane project in relation to these themes appears to be an uncomplicated case of appropriation of old springs. The city of Rome is renewed by a re-assertion of her inevitable titanic condition. New water outlets may be provided but these are not new springs. An old water supply system is patched up by Pope Sixtus V, and fertility and prosperity for the city of Rome and its rulers is assured by the presence of images of the old river gods.

The topos of rebirth is related in this paper to the architectural use of stone. Keats's imaginative empathy for stone; as statuary, or mountain ravine and crag; relates readily to Michelangelo's technical expertise with stone. The use of stone is problematic for contemporary architects in relation to Donato's reading of Keats. Is stone dead? Can it, should it be revived? Is there a new lightweight contemporary stone Apollo about to be born? Can the Humpty Dumpty pieces of an antique stone world be put together again?7 Is a new stone architecture inevitably a titanic appropriation of archaic building? Does a stone crypt suffice?

Consideration of these themes and texts by undergraduate architecture students in several design-studio sessions since 1984 at the Auckland University School of Architecture is referred to in this paper with brief reference to the fortunes of the institution of the University. Discussion of several students' designs involves mention of their own architectural and sculptural references and the crossreferencing of these with still further references. Such is the nature of design.

\section{A DUMP: THE FAIREY CRYPT}

For under the building in which this paper was first read Roger Fairey in 1985 proposed a crypt. ${ }^{8}$ The brief was for an architectural museum to be associated with the Auckland School of Architecture. Fairey's design is a dissertation concerning Terragni's Danteum project of 1938 for the Via delle Imperio at Rome, part of a larger scheme concerned with the twentieth century renewal and restoration of Rome. 9

Fairey's design involves a labyrinthine journey down through interconnecting galleries and voids, penetrated by, and confronted with solids, according to the schema of the forest, descent into inferno, and ascent through purgatory and paradise. Various archetypes and fragments of previous forms are encountered in this layering of space conducive to memory. A centring axial grid relates these complex interpenetrating forms with the circulation patterns within, and around, existing buildings. 
Fairey, as did Eugene Viollet-le-Duc, assumed that we 'will be struck with awe and respect in penetrating into these subterranean chambers.' And that relics 'enclosed within a darksome place, far from vulgar observation ... placed in the innermost recess of a narrow crypt approachable only by traversing several successive grottoes, diminishing as we advance.' 10 will be permanently respected just as the older relics had been respected before their translation to exhibition on altars in the Gothic churches above.11

The current architecture faculty administration at Auckland was horrified at Fairey's proposal saying an underground space denied everything the existing buildings stood for - fresh air, sunlight, openness, greenery. This protest is an account of what can be termed, employing Donato's terminology, the redemptive schema of modern architecture's Apollonian topos, which requires the absence of the crypt. The Auckland School of Architecture has nevertheless extensive basement accommodation.

Suppression of the crypt has been recently scrutinised by Wigley (1987). Wigley cites Derrida's observation:

The ground on which the foundations of the house are laid is necessarily unsafe, undermined by the crypt: the terrain is slippery and shifting, mined and undermined. And this ground is, by essence an underground.12

The structure of Fairey's entrance-shaft 'crashes through the School's existing foyer'. He specifically states this on the drawing. Its throat in steep descent passes a library (colour remains above), and reaches down to rest at the edge of the forest. From here an abyss can be discerned. There is a mezzanine at a lower level then a gallery at what he terms 'a lower than lower level' skirting the abyss with inferno alongside. A ramp spirals round a huge conical column, through the galleries of purgatory, eventually breaking out to the court above.

A process of refinement of detail can be seen at work in Fairey's drawings. Comparison of the profiles of the column capitals in the underground forest can be made with a bronze incense burner, from Paros perhaps, of the mid 5th century BC, found at Delphi, and now in the New York Metropolitan Museum. It is $34 \mathrm{~cm}$ high and perhaps depicts Athena helping Herakles temporarily replacing Atlas in his task of supporting the earth. Athena's upraised supporting arms make a graceful papyriform outline as in Fairey's design. 13 Here is a hint of the Olympian mission, of lightness and grace displacing titanic muscularity.

\section{INTERLUDE: STONE TOPOS}

Fairey's design for an underground museum of architecture makes extensive use of
10. E Violett le Duc, Lectures on Architecture, translated by B Bucknall, 2 Vols, London: Sampson Low, 1877; p. 23.

11. Paul Theodore Frankl, Gothic Architecture, Penguin, 1962; p. 226.

12. Mark Wigley 'Post Mortem Architecture, The Taste of Derrida', in Perspecta 23, 1987. Jacques Derrida translated by Samuel Weber in 'Limited Luc', Glyph 2, Baltimore: John Hopkins University Press, 1977, p. 168.

13. Greek Art of the Aegean Islands, New York: Metropolitan Museum of Art, 1979; pp. 228-229. 
14. The recent publication by the Geological Society of New Zealand; Bruce Hayward, Granite and Marble: A Guide to Building Stones in New Zealand. Guidebook No. 8, Lower Hutt, 1987; indicates a specific interest in stone building in New Zealand.

15. I am grateful to Auckland architect Neil Kirkland for directing my attention to Auckland's many basalt constructions; and for his enthusiasm for stone in all its forms.

16. Homer, The Iliad, translated by Robert Fitzgerald, Oxford, 1984; p. 392.

17. An index of this attitude could be indicated by the lack of a masonry workshop at the Auckland School of Architecture although it has fully equipped carpentry and metal workshops. There are several recent undergraduate theses at Auckland concerning the use of stone in architecture. This may suggest a renewal of interest in building stone amongst local architects. The theses include: Diane Burgess 'Building in Stone', 1979; Janine Boyd 'Detail in Stone Building', 1984; Jenny Rattenbury 'New Zealand Rock Formation and Architecture', 1985.

18. Hayward, 1987, p. 10.

19. Donato, 1979 , pp. $94-95$ and p. 118.

20. Christopher Wood, Olympian Dreamers. Victorian Classical Painters 1860-1914, Constable, London, 1983, Chapter 3, 'Sir Lawrence Alma-Tadema', Chapter 4, 'Sir Edward John Poynter'. stone, and thus, as a stone crypt, on two counts makes that which is supposedly absent central to the architectural imagination; for in progressive architectural circles in New Zealand there has been a myth concerning New Zealand's lack, not only of crypts, but of stone buildings generally.

This myth is not shared in geological circles.14 In Auckland it is not unusual for current demolition of inner city buildings to expose crypts constructed of local basalt.15 Their stones are mute, uninscribed and unremarked upon, recumbent at the edge of each excavation's abyss; their location perhaps measured for a day, or week, by hurrying archaeologists before these stones are replaced by even larger crypts. Basalt blocks are also used as curbing stones for Auckland's city streets like in the streets of Pompeii. These basalt blocks are used as was Hector trailing from Achilles's chariot, dead underfoot:

$\ldots$ and the head so princely once

lay back in dust...

So his whole head was blackened. 16

for in New Zealand the notion that stone is dead has been widespread and long held. 17

The oldest standing building in New Zealand of European design, the Keri Keri Stone Store, Bay of Islands, built 1832-1836, has walls made of the local basalt. Yet its arches, quoins and keystones are made of imported Sydney sandstone which Hayward (1987) remarks 'was much easier to dress'.18 Athena assisting again perhaps? Or a graceful instance of titanic appropriation of the birth of New Zealand's European architecture; for these sandstone blocks are the large structural stones in the design.

Connected with this view that stone is dead are commonly held attitudes to stone in architectural history. The very word Egypt has become an acoustic of death and of the entombment of stone inevitably buried under both desert sand and its own weight and bulk. This acoustic is noted by Donato as the song of mourning heard by Flaubert and Keats in Egypt. A mourning, Flaubert observes, for the withdrawal of the Gods.19 Other Olympian dreamers, notably Lawrence Alma-Tadema and Edward Poynter, have shown just how sweet this mourning can be by their nostalgic evocation of the delights of the marble patina of a past golden age.20

If Egypt gives profound confirmation of the death and entombment of both the Gods and stone itself, it has also from the outset linked stone with the problem of birth and the theme of renewal, as at Zoser's funerary and Heb-Sed jubilee renewal complex where it seems the fresh beginnings of stone architecture are concerned with conscious reference to the primeval beginnings of life and to its continuation. 
Temple, palace and tomb are inseparably linked with the birth of the gods, and with rebirth in death. Here, from the outset, stone delicately at first, and then with a rapidly increasing force which never loses this delicate reference, continues to appropriate the reed booth. 21 As birth is a prior condition for existence, so stone can be seen as a prior condition for civilisation. As birth for the continuation of life in the face of death, becomes a repeatable imperative, so the continuation of civilisation in the face of extinction requires that the architecture of stone be repeated. Thus it seemed to the Renaissance mind preoccupied with the theme of rebirth, seeking out antique stones for their inscriptions, design, and position in larger compositions; and these made the subject of learned references in brick and stucco, painting and sculpture, just as Romans before had done; referring in fresco and stucco both to an Archaic or Classical past, and to recent, and contemporary, architectural innovations. 22

Perhaps the theme of rebirth in relation to stone has not been advanced further than the Byzantine mind. References, in glass and stone chips as mosaic tesserae, to the spatial nuances of Archaic, Classical and Hellenistic figure sculptures' posture, outline, arrangement and polychromy (as lively as contemporary magazine and poster graphics) were it seems, intended to spiritually transcend the substance (the weight, volume and texture), of earthly stone. In the presence of this spiritual reality, prefiguring types and shadows are acknowledged only by their absence. Stone, spiritually incomplete, is no longer required of itself.23 Humpty Dumpty's myriad stone fragments are reassembled into a new spiritual design, with the help of the King's men - chiefly the Apostles, with numerous Saints, Warrior Saints and Heavenly Beings. Not for nought the presence of the quadriga of gilded copper horses, which once presided somewhere over Constantinople's Hippodrome and Augusteum, and latterly over the Piazza di San Marco in Venice, from the base of the vaults of the Basilica of St Mark. Such horses reappear later, with Apollo as their Charioteer, as the focus of the watergardens at the Palace of Versailles.

Beneath the Byzantine vaulted, spiritual polychromy, is stone, in the guise of its earthly self, as massive piers, and surface patterns of marble depicting the fertility of a watered earth, as wall revetments and floor slabs. To the Mesopotamian mind this stone world below is an inferior doomed world, its cipollino patterns intimating the deluge. To the Greek mind, it is Mount Olympus providing access with the help of gods, heroes, and Christian Saints to the heavens.24

Keats, in depicting Hyperion's palace, draws on the imagery of these Constantinopolitan vaults, jarred repeatedly by earthquakes, and Constantinople's two falls, and jars them further with his own doubts, re-integrating their heavenly conceits with their earthly origin:
21. Jean Phillipe Lauer, Saqqara: The Royal Cemetery of Memphis, London: Thames and Hudson, 1976.

22. Vincent J Bruno, 'Antecedents of the Pompeian First Style', in American Journal of Archaeology, 73, 1969; pp. 305-317.

23. Gervase Mathew, Byzantine Aesthetics, London: John Murray, 1963.

24. Kathleen E McVey, 'The Domed Church as Microcosm; Literary Roots of an Architectural Symbol', in Dumbarton Daks Papers, 37, 1983; pp. 91-121.

overleaf

1. Jasper van der Lingen, Saturn - Kauri Fountain for the University of Auckland (1986).

2. Linley Hindmarsh, Hyperion Fountain for the University of Auckland (1989).

3. Richard Ried, Hyperion Fountain for the University of Auckland (1988).

4. Denise Wright, Hyperion Fountain for the University of Auckland (1989). 

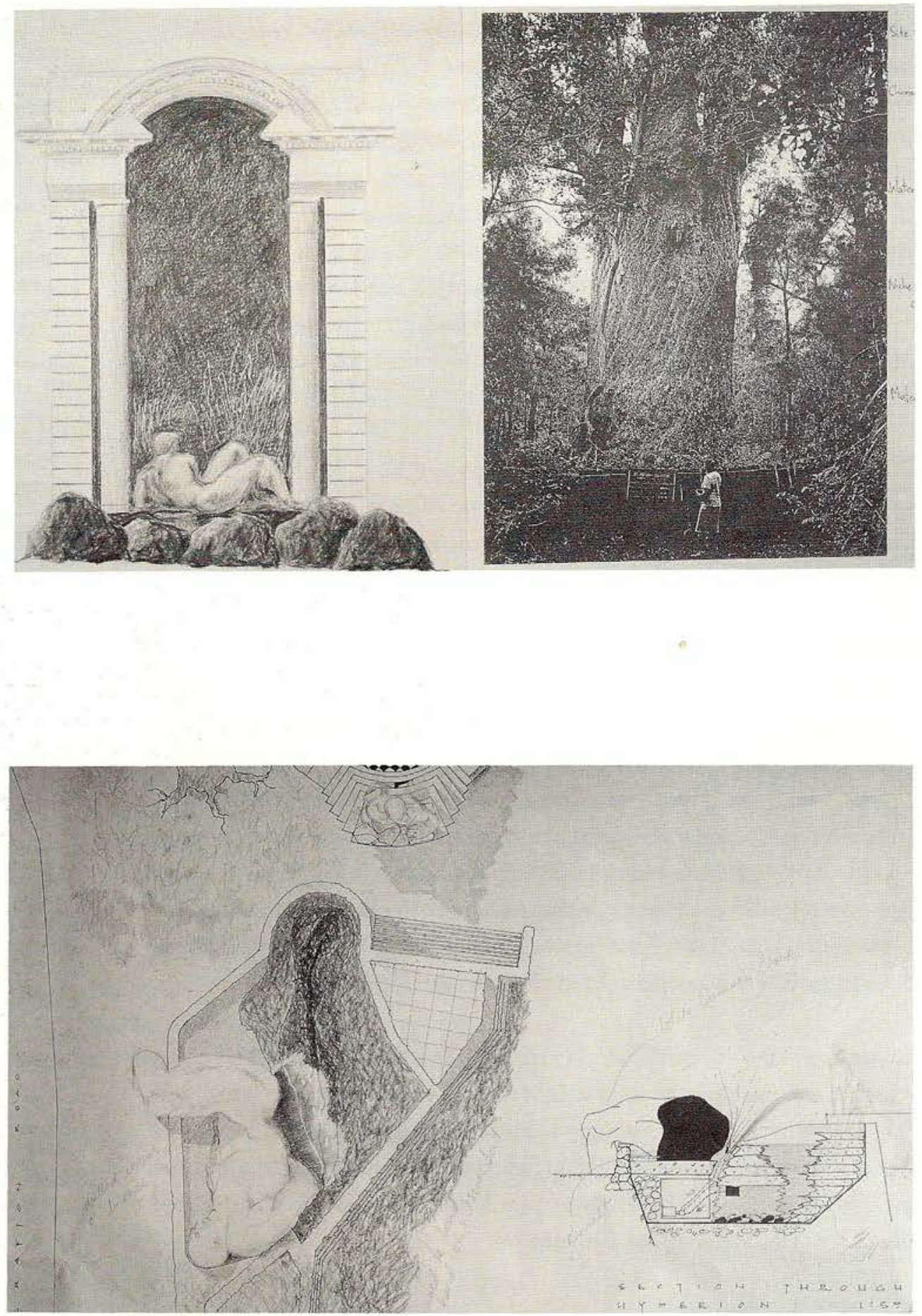

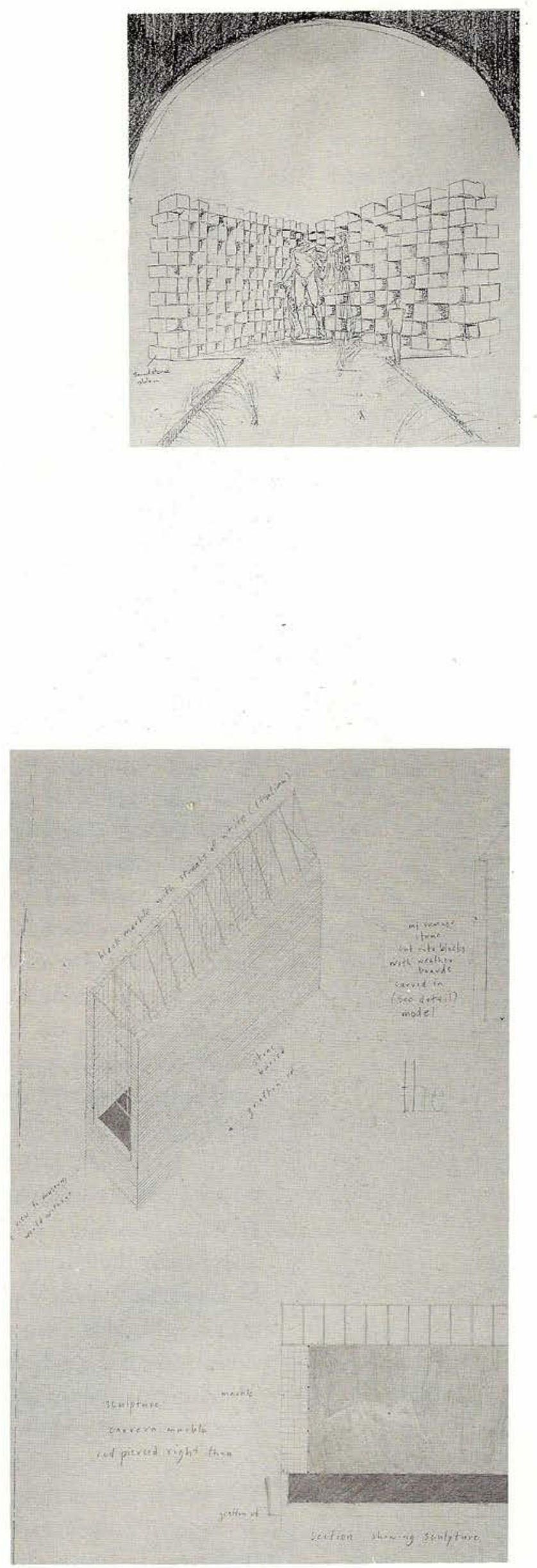
25. John Keats. The Complete Poems, edited by John Barnard, Penguin, 1976. All quotations from Keats's poems are from this volume.

26. H.V. Morton, The Waters of Rome, London: Rainbird, 1966, chapter VIII, 'The Aqua Felice and its Fountains'. See also Anthony Blunt, Borromini, London: Allen Lane, 1979, chapter 3, 'S. Carlo alle Quattro Fontane'.
He entered, but he entered full of wrath;

His flaming robes streamed out beyond his heels, And gave a roar, as if of earthly fire,

That scared away the meek ethereal Hours

And made their dove-wings tremble. On he flared,

From stately nave to nave, from vault to vault,

Through bowers of fragrant and enwreathed light,

And diamond-paved lustrous long arcades,

Until he reached the great main cupola.

There standing fierce beneath, he stamped his foot,

And from the basement deep to the high towers

Jarred his own golden region...

Hyperion A Fragment, Book 1 (213-224) 25

A Hump: van der Lingen's and Hindmarsh's Quattro Fontane and Wright's and Reid's Apollo

The Quattro Fontane of 1588 is part of Pope Sixtus V's pleasant space of urban theatre, shaped by the Porta Pia facing into the city of Rome toward the Quirinal Palace, with the Via Pia between. The Quirinal also faces across the grander space of the Tiber river valley to the Vatican and S. Pietro. Its long sleeve (manica lunga) reaches along the Via del Quirinale from the sculptural group of the Dioscuri on Monte Cavallo. These figures, over six metres high, of Castor and Pollux, the socalled horse tamers and their horse, are believed to be Roman copies of the 4 th $/ 5$ th century BC Greek statues found in the Baths of Constantine. Their fake inscriptions - attributions to Phidias and Praxiteles - have been renewed as 'friendly voices' by Sixtus V. The long sleeve of the Quirinal reaches toward the Quattro Fontane at the intersection of the Via Pia with the Via Felice, extending toward S. Maria Maggiore - a centralising grid connecting with the circulation patterns of the existing buildings. Obelisks, symbolising renewal, can be seen in each direction from this street intersection at the top of a hill, below which, is the building in which Keats died.

A short distance further toward the Porta Pia, is the terminus fountain, the Fountain of Moses, of Sixtus V's Aqua Felice completed by Fontana in 1587. Its water feeds the Quattro Fontane and the Capitol beyond the Quirinal. Thus as Morton (1966) relates, the Aqua Felice brought water back to the Capitol (1588), after thirteen centuries, from springs fifteen miles east of Rome, fed by water from the Alban Hills, that has filtered through volcanic tuft, and which reaches the city from the springs in twelve hours. The old Claudian and Marcian aqueducts are used by Sixtus $\mathrm{V}$ along the way in this most expensive, most generous, of his works. 26

The four fountains of the Quattro Fontane are four figures: Fidelity with a dog, Strength with a lion, and the river gods - the Tiber, and its tributary the Anio from the Sabine Mountains to the East of Rome. Or perhaps it is the Nile. The Tiber is 
lodged in the corner of Borromini's S. Carlo alle Quattro Fontane, the design of which also springs from the Sabine Hills, as Borromini's inspiration seems to have come from the then contemporary excavations at Hadrian's villa at Tibur.27

The Quattro Fontane river gods continue the tradition of the old Roman sculptures of the river gods of the Nile and Tiber (formerly the Tigris), sited at the Quirinal and removed by Michelangelo to the Capitol, where he placed them beneath the stairs of the Senate in a composition comparable to that in which the river gods were intended to participate in the New Sacristy of San Lorenzo in Florence. Symbolic of renewal these statues are a tangible continuity with ancient Rome, being two of the few Roman sculptures to survive uncovered from ancient times.

Gais (1978) in her quest for the sources of river god iconography argues the reclining river god as an Hellenistic synthesis from Alexandria, achieved by the 4th century $\mathrm{BC}$, and inspired by the river Nile; a synthesis of the reclining banqueter, particularly Herakles, with his antagonist the archaic river god Acheloos. 28

In the role of river god, Herakles, a popular comic character in his drunken recline, is also a moral exemplar of stoic philosophy reclining justly from his ethical struggles. He is a powerful protective hero, holding a cornucopia in the role of an agricultural fertility god, feasting with Dionysos at ritual banquets with initiates in honour of the gods, or in honour of the deceased at funeral banquets. He is the giver of prosperity, the river, a source of life, and here at the Quattro Fontane he is the river Tiber, or perhaps the Nile, presiding over the city of Rome's renewal.

Moore (1960) suggests fertility is a dominant theme of the extensive hydraulic conception of Hadrian's villa at Tibur.29 Renewal is a likely preoccupation of Hadrian. Gais's analysis brings Zoser's renewal complex at Saqqara on the banks of the Nile into sympathetic relation not only with Hadrian's villa at Tibur, where renewal of the Emperor in at least a recreational sense can be considered a theme, but also with Hadrian's mausoleum on the banks of the Tiber.

The Capitol at Rome receives water from Sixtus V's Aqua Felice, and is also the repository of the reclining figure Marforio, perhaps symbolising the ocean, an old Roman sculpture from the forum placed on the Capitol by Jacopo della Porta in 1594.30 Marforio is a talking statue, as is also Rome's Pasquino depicting Achilles lifting the body of Patroclus whom the immortal horses bore away as rivers do. 31 These horses are the subject of Angelos Sikelianos's poem The Horses of Achilles:
27. Blunt, 1979, p. 37.

28. Ruth Michael Gais, 'Some Problems of River God Iconography', in American Journal of Archaeology, 82, 1978, pp. 335-370.

29. Charles W Moore, 'Hadrian's Villa' in Perspecta 6, New Haven, 1960, pp. 16-27, p. 19.

30. Morton, 1966, pp. 148-154.

31. Fitzgerald, 1984, p. 299.

... Their backs gleamed like a wave;

they came up out of the sea,

tore over the deserted sand,

necks straining high, towering,

white foam at the mouth, stallion-strong, 
32. Angelos Sikelianos Selected Poems, translated by Edward Keeley and Phillip Sherrard, London: Allen and Unwin, 1980, p. 13.

33. Jacques Girard, Versailles Gardens. Sculpture and Mythology, translated by Ellen Rosenthal, London: Sothebys, 1985, 'Seine', p. 230 and 'Rhone', p. 239.

34. Jasper van der Lingen graduated in Architecture from Auckland University 1988.

35. John Morton, John Ogden, Tony Hughes, Ian MacDonald, To Save a Forest, Whirinaki, Bateman, Auckland, 1984. The Kahikatea reaches 65 metres in height, the Totara 55 metres, the Rimu 65 metres. See also S W Burstall and E V Sale, Great Trees of New Zealand, Reed, 1984, pp. 19-20. The giant Kauri Tane Mahuta, 51.5 metres high in the Waipoua Forest has a trunk 17.68 metres high and 13.77 metres of girth. Te Matu Ngahere, also in the Waipoua Forest, has a trunk 10.21 metres high and 16.41 metres of girth.

36. Hayward, 1987.

37. See Carlo Scarpa, edited by Toshio Nakamura, Tokyo: B\&U Publishing Co, 1985.
... The hero held the reins;

he spurred, hurling

his godlike youth forward . . 32

The cross referencing of the themes of Achilles and Patroclus, of Hadrian and Antinous, of Achilles' horses achieving the Olympian redemptive mission, of Hadrian's Antinous cult, of the Nile repeatedly appropriated by Rome, as in the titanic raising of obelisks, and as in its Nile fountains and river gods, is beyond the scope of this paper. Nevertheless a third royal renewal complex, that of Louis XIV at Versailles, must be linked with those of Zoser and Hadrian, and the river gods such as Jean Baptiste Tubi's 'Rhone', and Etienne le Hongre's 'Seine' recalled.33

In inviting undergraduate students (1986 studio session) to prepare designs of four fountains at a hill top street intersection within the University of Auckland, making reference in their designs to the Quattro Fontane and Keats's Hyperion, students were seen as participants in a ritual banquet, as initiates, or banqueters feasting in honour of the deceased, in honour of a cultural heritage of which the Quattro Fontane and Hyperion are part. Through their designs all students would be invited to join in the feast. The whole University is seen as such a cultural banquet, advantageous to society, for its prosperity and wellbeing, protecting society's interests, and fostering its renewal. Such was the programme for the design.

In Jasper van der Lingen's design the river gods of the Quattro Fontane are transplanted directly with their niches and foliate grottoes. 34 Not only does Herakles become merged in body with Keats's Titans, but the foliate backgrounds also assume the titanic condition Keats has imagined:

\footnotetext{
Deep in the shady sadness of a vale

Far sunken from the healthy breath of morn,

Far from the fiery noon, and eve's one star,

Sat grey-haired Saturn, quiet as a stone,

Still as the silence round about his lair;

Forest on forest hung above his head

Like cloud on cloud...
}

Hyperion. A Fragment, Book 1(1-7)

Saturn reclines specifically sixty five metres beneath the deep shade of New Zealand's indigenous titanic trees, the kauri, totara, rimu and kahikatea; each tree separately carved into stone for one of the four street corners.35 Van der Lingen accommodates also the delicate forest floor plants associated with each tree, contrasting these with the titanic assertion of the huge trees. New Zealand stones, 36 Coromandel tonalite and Oamaru limestone, are blended with Carrara marble in rhythmic stepped progressions in the manner of Carlo Scarpa. 37

Van der Lingen has achieved a heavy, deep sense of fecundity; a sense of strength 
in times past, of wealth and resource, a funding of society's enterprises. Yet the wind stirs uneasily, the mind drifts through an awful sadness. In some of the sculpted forms there is an exceptionally sweet song of mourning; for each tree god follows the contours, texture, and profile of its namesake tree. Because of this emphasis on timber the mind drifts to other timber forms; perhaps to the Maori canoe Mata-atua uplifted at Whakatane and rescued from drifting further, after coming to rest in the Bay of Plenty as part of the first landfall of the Arawa tribe. 38

In van der Lingen's design the heavy masculinity of the tree gods, their basso profundo slowness, the funeral ensemble of stelae, all assert the 'nest of woe' of the assembled Titans as encountered by Saturn and Thea:

... Above a sombre cliff

Their heads appeared, and up their stature grew

Till on the level height their steps found ease,

Then Thea spread abroad her trembling arms

Upon the precincts of this nest of pain...
38. Errol Braithwaite, The Companion Guide to the North Island of New Zealand, Auckland: Collins, 1970; pp. 399-400.

39. Linley Hindmarsh graduated in Architecture from the University of Auckland 1989.

One feels unease at the ominous threat of uprooting engendered by van der Lingen's giant trees.

Linley Hindmarsh's approach is a lively narrative one accenting the vigour of the battling giants as a prelude to the Titans' realisation of failure and their consequent lethargy. ${ }^{39}$ Her groupings refer to Hellenistic theatrical treatment of the subject, and to Orsini's 16th century battling giants at Bomarzo, and Giulio Romano's Sala dei Giganti in the Palazzo del $\mathrm{Te}$ at Mantua. Initially her design entertained a fragmented screen of columns and entablature entwining motor traffic with struggling giants but this was abandoned in favour of an intense consolidation of the four street corners.

Hindmarsh's vivid sense of colour and texture makes use of black basalt, red volcanic scoria, white Oamaru limestone, and purple, green and black hyperite. With these stones she evokes an abyss over which Hyperion is poised.

By cross referencing the Quattro Fontane with Keats's evocation of the Titans, the cheerful, after-dinner somnolence of the traditional river god type is profoundly disturbed. Forms of muscular repose; creamy sweet of limb, oiled sleek, slack aging Olympians, as depicted in Tubi's 'Rhone', and le Hongre's 'Seine', at Versailles; become tensed. Herakles's indulgent lassitude becomes a case of the post-labour blues, implying doubt concerning the success and outcome of his labours. Herakles is edged by Hindmarsh to the brink of despair.

Van der Lingen displaces these doubts with the optimism of the colossal, as did 
40. The Nile, Chiaramonti Museum, Vatican, Rome.

41. Gerald van der Kemp, Versailles, Park Lane, 1981; pp. 206-207. See also Girard, 1985; pp. 150-151.

42. Girard, 1985; pp. 222-223.

43. E Viollet-le-Duc, Dictionnaire Raisonne de l'Architecture Francaise du XI au XVI Siecle, Paris, 1875, Volume VII, 'Pierre'; pp. 121-130.

44. Denise Wright graduated in Architecture from the University of Auckland 1989.
Michelangelo, to whose river god studies and figures for the New Sacristy, van der Lingen refers. But no matter how high these giants lift their stature; no matter how far they extend their arms; doubt gnaws at their roots, exactly where the tree gods lie.

In these designs the river god type moves far from the amiable Nile, besotted with a progeny of putti nomes, in assurance of untroubled continuity of life.40

Van der Lingen's assertion of the colossal requires further cross referencing. It occurs at Versailles with Gaspard Marsy's 'Enceladus' fountain. Here, an almost totally engulfed figure, with only hands free for leverage on the rocks, manages to eject from an anguished mouth a seventy five foot jet of water upward into the air.11 The titanic force of this water is rooted in Enceladus' throat depicting the reassertion of power in full redemptive force. Just as Fairey's underground museum's entrance shaft crashes through to the surface. By comparison Tubi's 'Apollo' fountain, at the focus of the Versailles garden is a frilly, frivolous frolic. 42

Titanic determination comparable with that of Marsy's 'Enceladus' is demonstrated by the Cathedral of Notre Dame in Paris, as grasped by the imagination of Viollet le Duc, and carefully described by him in his Dictionnaire. 43 He relates how for strength, the foundations, piers and columns of the building, have rebuilt the geological disposition of the stone as it occurs in the quarry beds from which it is taken. That which appears vertical to the eye, particularly the columns, is in fact a composition of horizontals. Each layer of stone has been placed in the building just as it was under natural compression adjacent to the layers of its accustomed neighbours. This geological conception of the building's design; its reference to its under construction, to its own underground pre-life; is a triumphant re-assertion of form and secures for the Cathedral its full redemptive function. This geologically conceived form is a renewal of an age-old continuity in the face of the fractured counterpart of the purging blast of its construction: for quarry beds have been decrypted, split asunder; chips, flakes, showers, clouds of grit and dust have been with the demons blasted off, or not quite, for fine sculpting of the uplifted form renders its titanic construction in Olympian dress.

Denise Wright in her design for the four university fountains refers to the explosive force which the Titans withstand, retaining the integrity of their own form, but which places their dominion into other hands.44 She depicts the fall of the Titans by means of a descending water stair, and then through a ritual subterranean passage of entombment, provides a view of the triumph of light: a sleek Apollo Belvedere, well turned out, with a fitted sandstone wall behind composed of small blocks arranged in an open pattern. Fragments from an explosion can be formed into many intriguing geometrical patterns; in which Apollo delights, and which may well furnish the realm of the visual arts and music; but these fragments cannot be formed 
into Titans.

The recent rebuilding of the colossal twenty four foot seven inches high statue of Ramesses II from the Temple of Ptah at Memphis demonstrates the distinction between Titan and fragment. 45 The reconstruction is convincing because of the three large remaining blocks: head and shoulders, torso, and thighs. The shattered kneecaps and heels, although restored, remain fractured. The whole figure is reinforced from behind with a wall-pillar. The device of an anterior wall seems coincident in cases of colossal resurgence and will be encountered again when discussing the Sistine Chapel.

These ancient stones constituting the Ramesses colossus which have lain horizontal at Memphis for several millenia, are now in relation much as quoin stones are to the lesser stones of a wall as in New Zealand's oldest standing stone building of European design already referred to in this paper. The raising of the colossus of Ramesses; an act of titanic reassertion; is concerned with the theme of renewal of Ramesses II, and of the renewal of Egypt.

It can be noted that the reclining sculpted figure of Marforio previously discussed, and now on the Capitol at Rome, has similarly suffered fractures of the heel and arms. Jacopo della Porta restored these extremities to the torso. He also built a high wall behind the sculpture defining the position of the Capitoline Museum in Michelangelo's Capitol design. A central niche located Marforio in this wall. Eventually when this wall was replaced by the Capitol Museum, Marforio was moved to the courtyard.

In Wright's design Apollo Belvedere, like Bandinelli's 'Orpheus' in the courtyard of Michelozzo's Palazzo Medici-Riccardi in Florence, 'paws up against the light' as Keats has activated the horses of Imagination's chariot:

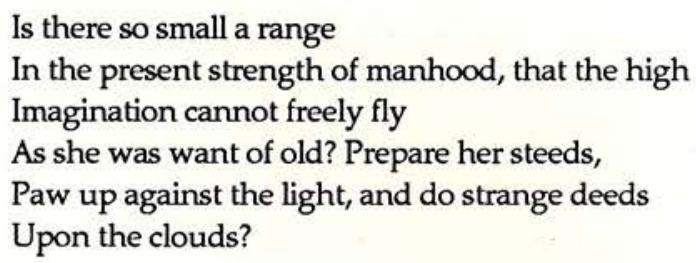

Richard Reid makes Oamaru limestone refer, in his design, to New Zealand's ubiquitous timber weatherboard wall cladding. 47 Its characteristic stepped profile is carved into the stone sides of a vertical fountain tank containing a sculpted Hyperion in free fall with water running down with him.

In both Reid's and Wright's designs, stone in lightweight guise supercedes or
45. Rita Freed, Ramesses the Great, Memphis: St Lukes Press, 1987.

46. Morton, 1966, p. 154.

47. Richard Reid graduated in Architecture from Auckland University 1988. 
48. Keats uses the image 'nervy kneed' to describe Endymion not his horses in Book I, p. 174. substitutes for the titanic impulse: just as Zoser's renewal complex makes reference in stone to delicate reed architecture, and as Notre Dame in Paris, notably by means of its rayonnant rose windows, refers to delicate organic forms.

The stepped profiles of Reid's stone weatherboards evoke the numerous tramplings of Keats's first sighting of the Charioteer's 'nervy kneed' horses. 48

... for lo! I see afar,

O'er - sailing the blue cragginess, a car

And steeds with steamy manes - the charioteer

Looks out upon the winds with glorious fear:

And now the numerous tramplings quiver lightly

Upon a huge cloud's ridge...

Sleep and Poetry (125-130)

The Fall: The New Sacristy of San Lorenzo, Florence and The Fall of Hyperion. A Dream

Cross referencing the New Sacristy with Keats's Hyperion furnishes much coincidence. The New Sacristy, with its semi darkness at floor level enveloping figures reclining on sarcophagi, is astonishirigly as Keats's has imagined the assembly of the Titans in their craggy lair:

... that sad place

Where Cybele and the bruised Titans mourned.

It was a den where no insulting light

Could glimmer on their tears...

Crag jutting forth to crag, and rocks that seemed

Ever as if just rising from a sleep,

Forehead to forehead held their monstrous horns;

... Instead of thrones, hard flint they sat upon,

Couches of rugged stone...

Hyperion. A Fragment , Book II (5-6, 10-16)

The atmosphere engendered by the Carrara marble wall tombs and protruding limbs of the sculpted figures is intuited by Keats:

Dungeoned in opaque element...

$\ldots$ and all their limbs

Locked up like veins of metal, cramped and screwed;

Without a motion...

... here found they covert drear.

Scarce images of life, one here, one there.

Lay vast and edgeways; like a dismal cirque

Of Druid stones, upon a forlorn moor.

Hyperion. A Fragment ， Book II $(23-26,32-35)$ 
intimately as he did the human body.

In the New Sacristy, the river gods envisaged beneath the sarcophagi are notably absent; unlike those Michelangelo positioned beneath the stairs of the Senate on the Capitol in Rome. The New Sacristy river gods were intended perhaps to be the four rivers of Hades, or of Paradise. Symbolic of fertility they set the scene for rebirth, but have given way to the image of the banqueting Herakles; four banqueters reclining upon sarcophagi in almost drunken torpitude. This is the scene of a funeral feast in honour of the deceased Medici. But cross referencing with Keats, these four figures are disposed as if on an operating table from Keats's medical years, with the vacant spaces beneath the table now an ominous indicator of the success of the operation. Bodies that have been borne away, not by Achilles horses, but by unseen rivers; or as in themselves these rivers reversing the imagery of fertility and renewal traditionally carried by river gods. The mortuary is evoked also, and the need for other horses unable to redeem the deceased. Keats depicts such a scene at Saturn's Temple:

\section{...'If thou canst not ascend}

These steps, die on that marble where thou art, Thy flesh, near cousin to the common dust, Will parch for lack of nutriment - thy bones Will wither in a few years, and vanish so That not the quickest eye could find a grain Of what thou now art on that pavement cold.'

The Fall of Hyperion. A Dream, Canto I (107-113)

Keats's reference to the 'quickest eye' and its focus on a 'grain' evokes his likely source of the operating table or dissecting room acutely. The reference to acute vision is of crucial connection with the design of the New Sacristy in which the direction of vision of each figure has been carefully calculated.

The familiarity of Keats with witnessing pain in hospital wards and his concern at the brutality of his superiors in the operating room 49 is focused on the steps of the Temple of Saturn in a sudden climax:

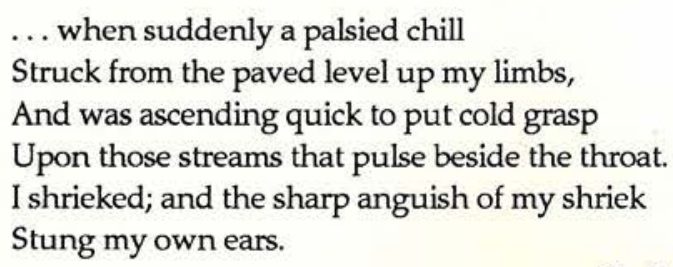

The Fall of Hyperion. Dream, Canto I (122-127)

In this cry of anguish there is also the acoustic of survival; of birth and of death in birth witnessed perhaps by Keats. This scene occurs also in Hyperion:
49. Robert Gittings, John Keats, Penguin, 1985; pp. 102-103. 
50. Cox-Rearick, 1984, argues the traditional figure of Lorenzo as actually Giuliano, p. 235. The two figures of Lorenzo and Giuliano are named and described in this paper accordingly.

51. Cox-Rearick, 1984, p. 42

52. Plato, Phaedo.
... Thus the God,

While his enkindled eyes, with level glance

Beneath his white soft temples, steadfast kept

Trembling with light upon Mnemosyne.

Soon wild commotions shook him, and made flush

All the immortal fairness of his limbs -

Most like the struggle at the gate of death;

Or liker still to one who should take leave

Of pale immortal death, and with a pang

As hot as death's is chill, with fierce convulse

Die into life; so young Apollo anguished.

His very hair, his golden tresses famed

Kept undulation round his eager neck.

During the pain Mnemosyne upheld

Her arms as one who prophesied - At length

Apollo shrieked - and lo! from all his limbs

Celestial...

Hyperion. A Fragment， Book III (120-136)

Coincident with Keats's acute acoustic reference is his acute awareness of the eye and the significance of angles of vision. This control of vision is a crucial aspect of the arrangement of the sculptures with in the New Sacristy. Just as Thea when accompanying Saturn climb up to the Titans' craggy lair 'Sideways long fixed her eyes on Saturn's face' (Hyperion. A Fragment Book II, 91), so Giuliano and Lorenzo look sideways to the Virgin and Child, at the focus of the New Sacristy, placed also to receive direct vision of the celebrant priest at the altar.

Neither Lorenzo nor Giuliano actually wink at the Virgin Madonna, presumably for decorum's sake. Yet taken together, with Lorenzo's head inclined upward, and Giuliano's head downward, the mechanism is present. 50 This pattern is even more extensive, if less focused in the arrangement of the four figures upon the sarcophagi; a dreary succession of dawn and day, and dusk and night; perhaps symbolic of the uninterrupted cycle of prayers of intercession for the deceased; they are grouped in two pairs with faces alternatively lifted up and down.51

If each pair of reclining figures are thought of as the eyes of each wall tomb, with the figures of Giuliano and Lorenzo each the bridge of the nose, and the sarcophagi as the mouths, then with this metaphor comes an awareness of the rhythmic motion of one eyelid up, one eyelid down each side; a gesture thrown by Giuliano and Lorenzo, rhythmically to the Virgin, one eyelid up, one eyelid down: repeated yet again in the fractured lids of the sarcophagi, and terminated by their scrolled ends, just as the eyelid itself is inherently a closed form following the curvature of the eyeball. Is Michelangelo winking an eye at Plato's theory of opposites?52

If the theme of the tomb is fertility, procreation, and renewal arising from the seasonal rhythm of the great rivers and the passage of time with its day and night 
cycle; for which the Madonna and Child is the transcending symbol; then a vulgar reference such as the wink is not irrelevant as a symbolic guarantor of life. 53

... Did my very eye-lids wink

At speaking out what I have dared to think.

Sleep and Poetry (299-300)
53. Humour in

Michelangelo's character and work seems to have been largely ignored.

54. Following Cox-Rearick, Lorenzo here is the figure traditionally designated Guiliano.

A connection between winking and rebirth is implicit in the Apostle Paul's imagery:

We shall all be changed in a flash,

in the twinkling of an eye.

(I Corinthians 15: 51, 52 New English Bible.)

The link between natural procreative sympathies and the redemptive schema is less explicit in the term 'twinkling' than is expected in Pope Leo X's world. A wink, unlike the image of 'flash', implies languor of the body: specifically the weight and curvature of the eyeball and its covering lid. Here is a confirming response from the otherwise engulfing lassitude of the titanic sculptures of the New Sacristy; a response magnified rhythmically by the scale of the room.

But the first step in the titanic impulse toward appropriation of birth in the act of renewal is observed in the upright, seated posture of the figures of Lorenzo and Giuliano. In their godlike, forceful, upright stature, contrasting with the reclining sculptures beneath, these figures of Lorenzo and Giuliano imply the redemptive schema; at least a renewal of mortal life in this middle register betwixt immortality and death:

...'Thou hast felt

What 'tis to die and live again before

Thy fated hour.' ...

The Fall of Hyperion. A Dream, Canto I (141-143)

If Apollo can be seen to be in Michelangelo's mind Keats's Bacchus is there also, particularly in the figure of Lorenzo.54

... forms of elegance

Stooping their shoulders o'er a horse's prance,

Careless, and grand - fingers soft and round

Parting luxuriant curls - and the swift bound

Of Bacchus from his chariot, when his eye

Made Ariadne's cheek look blushingly.

In their slender upright proportions, particularly of Lorenzo's neck; as are poplars; one feels the apprehension of falling, as in van der Lingen's reference to the great trees: 
55. Hartt, 1971, p. 181.

If I do fall, at least I will be laid

Beneath the silence of a poplar shade;

And over me the grass shall be smooth-shaven;

And there shall be a kind of memorial graven.

Sleep and Poetry (277-279)

Implicit in these two registers of figures, reclining and upright, is the rhythm of rise and fall; as if the Medici not only are sustained and consumed by the natural cycles of day and night, the seasons, life and death, and time, but also ruled over these. From the contemplative stance of all these figures derives the despondency of this shortfall of eternal renewal, and like Keats's Titans, bewilderment at their failure. Oppressed by the enduring rhythms of which they are part, of fertility and death, the New Sacristy figures brood, incapable of achieving the redemptive short-circuit, or the extinction implied in the ambivalent image of Apollo's shriek. Subject to the all consuming destructive force of time: subjected to the ponderous alternation of the seasons and daily cycles, they groan,

\footnotetext{
Can I find reason why ye should be thus -

No, nowhere can unriddle, though I search,

And pore on Nature's universal scroll

Even to swooning, why ye, Divinities,

The first-born of all shaped and palpable Gods,

Should cower beneath what, in comparison

Is untremendous might. Yet ye are here,

O'er whelmed, and spurned, and battered, ye are here!

O Titans, shall I say, 'Arise!' - Ye groan ...

Shall I say 'Crouch! - Ye groan:'
}

Hyperion. A Fragment, Book II (149-158)

Yet in their titanic condition; in these base rhythms; there is available extraordinary force, as that depicted in Marsy's 'Enceladus' fountain at Versailles.

The explosive quality of release, of a pent up power, is indicated in Michelangelo's resurrection drawings for the New Sacristy; not implemented, presumably on account of Pope Leo's death. The resurrection of Christ - 'Rise up O Christ' - is also the theme of Pope Leo's Papal Bull against Luther. For the Roman Church likewise caught up in this titanic condition, the explosive concept of the resurrection, as enacted on Easter Saturday in front of Florence Cathedral at the festival of 'The Explosion of the Car' (Scoppio del Carro), provided an image for a redemptive short circuit, in the face of the Protestant challenge.55 This leads eventually to the Protestant birth being appropriated by the Roman Church in an act of titanic renewal as depicted in the Sistine Chapel.

Although the resurrection frescoes have not been painted in the New Sacristy their intent is implicit in the Sacristy's architecture; in the arcs of light, delineated by a 
dome, and pendentive vaults. Here is the realm of Keats's charioteer Endymion in 'a fair-wrought car, /easy rolling so as scarce to mar/ the freedom of three steeds of dapple brown.' Endymion (165-167). 56 But this realm above remains inaccessible and its presence glimpsed increases the despondency of those below who are returned to the realm of the river gods, and to renewed alarm at the absence of these, reinforcing the river gods function of 'carrying away'.

The visions are all fled - the car is fled Into the light of heaven, and in their stead A sense of real things comes doubly strong, And like a muddy stream, would bear along My soul to nothingness:

Sleep and Poetry (155-159)

In Keats's resistance there is the reinforcement of doubt:

... But I will strive

Against all doubtings, and will keep alive

The thought of that same chariot, and the strange

Journey it went.

Sleep and Poetry (159-162)

And the uplift of the New Sacristy's architecture is reversed, as is the gesture of the open sarcophagi below; open ready to receive the fallen just as the sea opened to receive Icarus and covered him.

Ah! rather let me like a madman run

Over some precipice! Let the hot sun

Melt my Dedalian wings, and drive me down

Convulsed and headlong!

Sleep and Poetry (301-304)

Michelangelo also, has depicted such a fall; that of the Charioteer Phaeton, in his presentation drawings for Tommaso Cavalieri, and also made use of this motif in his design conception for the Sistine Chapel wall.

Perhaps in apprehension of such a fall Keats's struggles with doubts and feelings of inadequacy as a poet. He is also oppressed by his brother Tom's illness. Oppressed by his 'identity pressed on his own', and which '... pulled on his senses'; 'identifying himself too-closely with the patient, in a self-destroying sympathy that should be reserved only for poetry.' 57 Thus he feels 'not yet a glorious denizen/ Of thy wide heaven.' (Sleep and Poetry, 48-49).

In the New Sacristy these emotions are encompassed by the uplifted dome: as an image for Keats's 'wide heaven' spanning the wide world below, which inspires Keats with the force of titanic resurgence:
56. Plato, Phaedrus. The allegory of the charioteer and his horses.

57. Gittings, 1985, p. 361. 
58. Hartt, 1971, pp. 88-89, p. 116, pp. 138-139, p. 181, p. 244.

59. Hartt, 1971, p. 249. It seems Michelangelo used this posture several times in both horizontal and vertical stances. Hartt cites en earlier reclining instance of this posture as Adam on the Sistine Ceiling and upright for an earlier resurrection study on the verso of the Tityus Sheet.

\author{
Then the events of this wide world I'd seize \\ Like a strong giant, and my spirit tease \\ Till at its shoulders it should proudly see \\ Wings to find out an immortality.
}

Sleep and Poetry (81-84)

If the dome of the New Sacristy is a symbol of heaven, or the planet's entire orb; like the complementing eyelid and eyeball; it is also the wide ocean - the watering of the eye. And this image too, after an initial calm, increases Keats's despondency by its titanic scale:

... an inward frown
Of conscience bids me be more calm awhile.
An ocean dim, sprinkled with many an isle,
Spreads awfully before me. How much toil!
How many days! What desperate turmoil!
Ere I can have explored its widenesses.
Ah what a task! Upon my bended knees,
I could unsay those - no, impossible!
Impossible!

Sleep and Poetry (304-312)

Despite the intent of the New Sacristy toward rebirth, the prevailing mood is that of titanic despondency, defeating the uplift implicit in its design. Although the delicate, sweet celebration of rebirth depicted in Pontormo's Vertumnus and Pomona fresco which depicts a similar arrangement of figures, eludes the New Sacristy; within the New Sacristy is a reservoir of titanic force of rhythmic intensity which becomes unleashed, as in the 'Enceladus' fountain, in the full blast of the Sistine Chapel's redemptive scenario.

\section{THE WALL: THE SISTINE CHAPEL, ROME}

Michelangelo's explosive resurrection studies, following Hartt's chronology, begin in 1512 with drawings for Julius II, for an unrealised painting above the altar in the Sistine Chapel. The theme is continued for Julius's Tomb and the facade of San Lorenzo and in 1520-5 with drawings for the New Sacristy in Florence, and then for Pope Clement VIII in 1532-3, again for the Sistine wall above the altar. 58 All these studies are transformed by the project for the entire end wall of the Sistine Chapel focussing on the triumphant figure of the resurrected Christ whereby titanic composure is asserted.

Apollo, if this be he, takes on a titanic Roman form. His square torso is like the trunk of New Zealand's giant kauri Te Matua Ngahere. Tityus is raised upright;59 as Ramesses II's colossus is, despite his shattered heels and knees. 
So on our heels a fresh perfection treads, A power more strong in beauty, born of us And fated to excel us,...

Hyperion. A Fragment, Book II (212-214)

Michelangelo appropriates this beauty with titanic force, requiring the entire wall to do so. The work contrasts with the perfection of his earlier studies of the resurrected Christ depicting:

.... Apollo! Young Apollo,

The morning-bright Apollo! 'Young Apollo!

Hyperion. A Fragment, Book II (293-294)

This act of titanic appropriation is like Zeus as an eagle swooping down to pluck young Ganymede from the earth; also the subject of a presentation drawing by Michelangelo.60 Keats understands how Ganymede's beauty is appropriated by Zeus:

... His youth was fully blown,

Showing like Ganymede to manhood grown;

Endymion

Book $1(169-170)$

But eagles golden-feathered, who do tower

Above us in their beauty, and must reign

In right thereof. For 'tis the eternal law

That first in beauty should be first in might.

Fyperion. A Fragment, Book II (226-229)

Michelangelo's colossus requires an entire wall. The colossus of Ramesses II required a reinforcing wall-pillar behind. Marforio was relocated on the Capitol with a high wall behind. Such is contemporary technique for reinforcing traditional stone work in both restoration and new stone building. There is subtlety in the walls of Carrara marble introduced by Michelangelo into the New Sacristy to back the wall tombs. Here, the white marble seems to dissolve the Chapel walls giving an illusion of Apollo's presence by an architectural means. 61

The Apollo-Christ of the Sistine Chapel is not a perky, nervy-kneed youth sitting atop a wall reaching to prune and hence create the fresh laurel growth as Portormo has depicted at Poggio a Caiano; he is a titanic Apollo, raised upright above the craggy lair of the damned, amidst the ponderous embrace of the blessed. In this multitude of accompanying figures; some, chiefly the Apostles and Saints, being of comparable or even greater titanic proportions than the keystone Christ figure, are like the large quoins and arches of a stone wall.

The overwhelming titanic force of the composition seems to preclude any
60. Hartt, 1971 , p. 249 . The Ganymede drawing is now lost but was given with the Tityus drawings to Tommaso Cavalieri, 1528-1533. Charles de Tolnay refers to Sebastiano del Piombo's suggestion that Ganymede, with a halo, be painted in the lantern of the Cupola for the New Sacristy. Charles de Tolnay sees this as a joke. Michelangelo. The Medici Chapel, Princeton, New Jersey: Princeton University Press, 1970; p. 50 .

61. de Tolnay, 1981, p. 39. 'Here, the walls seem to be pierced and dreamlike facades of white marble appear to loom on every side. It is like seeing through into another world where relations of height, width, and depth appear fleeting and deceptive (architecture which vaguely recalls the effects of the frescoes at Pompeii)'. 
62 de Tolnay, 1981, p. 63. nervousness. In Michelangelo's composition, there is not any hint of doubt, or despondency in the triumphant figures such as is aroused by the 'Apollo of the Bargello' sculpted at the cessation of the Florentine Republic.62 In this Apollo the problems of Keats's narrative can be discerned. The youth, particularly the beauty of the figure, is distanced, with consequent disturbing effect:

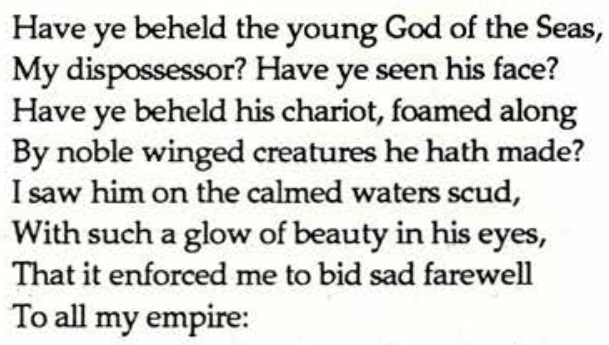

Hyperion. A Fragment, Book II (232-239)

The Sistine Christ-Apollo is all-present, through the titanic appropriation of youth and beauty. One wonders if this is the one for whom Mnemosyne, the Virgin of the New Sacristy, '... 'hath forsaken old and sacred thrones/For prophecies of thee, and for the sake/Of loveliness new born'.' (Hyperion. A Fragment Book III (77-79))

... Apollo then

With sudden scrutiny and gloomless eyes,

Thus answered, ...

Hyperion. A Fragment , Book III (79-81)

For the success of the redemptive schema, it seems that Humpty Dumpty is of little consequence; what matters is the rebuilding of the wall implying a stone by stone reversal of the fall. In this rebuilding of the wall the large titanic stones are crucial, whatever rubble is employed. Cannot then, the colourful fragments of Humpty Dumpty be arranged in artful patterns upon this wall as one pleases?

\section{Acknowledgement}

I would like to acknowledge the assistance of Auckland Architect Neil Kirkland as design tutor 